\title{
COMPUTER CONFERENCING, CRITICAL REFLECTION, AND TEACHER DEVELOPMENT
}

\author{
HEI.FN L. HARRINGTON and RIJSSEL S. HATHAWAY
}

The University of Michigan, U.S.A.

\begin{abstract}
The development of critical reflection in teachers is an issue of concern to teacher educators. Finding ways to foster that development becomes increasingly important as the schools continue to change with unprecedented rapidity. This paper reports the results of study that looked at whether computer conferencing could be used to help students of teaching become more aware of taken-for-granted assumptions - a crucial aspect of critical reflection. The following two questions guided our study. First, do conferencing activities generate opportunities for the identification and discussion of taken-for-granted assumptions and, if so, what types of assumptions? Second, do conferencing activities provide insight into the relationship between student development and the ability to identify and clarify taken-for-granted assumptions?
\end{abstract}

The range of what we think and do is limited by what we fail to notice. And because we fail to notice that we fail to notice there is little we can do to change until we notice how failing to notice shapes our thoughts and deeds. (Mezirow, 1991, p. 19, from R. D. Laing)

What we often fail to notice are taken-forgranted assumptions that give our lives meaning and coherence. This statement, of course, is loaded with its own taken-for-granted assumptions, some we are aware of and some we are not. If we make assumptions we are aware of regarding the preparation of teachers explicit, the reader will be better able to critique the discussion that follows. Of course, we can only address those we are aware of. The reader is cautioned to consider how those we are not aware of may have shaped our thoughts and deeds as educators.

One of the taken-for-granted assumptions we bring with us to this discussion is that knowledge is constructed, built on previous knowledge, coupled with experience, transformable, evolving, and consequential. A second is that teachers must be prepared to develop a sociocentric ${ }^{1}$ focus, one more encompassing than the self. An assumption supporting this is that one of the ways to break the bond of egocentricity is to provide students with opportunities to engage with individuals whose perspectives are different from their own. A final assumption guiding our work is that although we all impose an order to how we interpret the world - our philosophies of reality - that order is alterable. Education, one of the ways we construct knowledge, allows us to move beyond current ways of making meaning to ways of making meaning that are more open, permeable, inclusive, and integrated (Mezirow, 1991; Soltis, 1981). We assume the primary aim of education is development. Much of what we attempt to do as educators reflects that assumption.

The study discussed here is part of a larger study investigating whether computer conferencing activities can be used to foster the development of critical reflection in prospective teachers. In this paper we specifically focus on if and how a particular conferencing activity helped prospective teachers become aware of taken-forgranted assumptions - theirs, others, and the influence of those assumptions on their thinking. The following two questions guided our study. First, do conferencing activities generate opportunities for the identification and discussion of 
taken-for-granted assumptions and, if so, what types of assumptions? Second, do conferencing activities provide insight into the relationship between student development and the ability to identify and clarify taken-for-granted assumptions?

First, we discuss critical reflection and the relationship between critical reflection and taken-for-granted assumptions. Second, we present our rationale for considering computer conferencing activities especially suited to fostering critical reflection. Next, we discuss the methods employed in this study. This is followed by a discussion of the findings. We conclude with the implications of using computer conferencing activities to foster the development of critical reflection in prospective teachers - specifically in relation to taken-for-granted assumptions.

\section{Defining Critical Reflection}

Although there is general agreement that teachers should be reflective there is less agreement on what individuals mean by reflection (Calderhead, 1989, 1991; Grimmet \& Erickson, 1988; Richardson, 1990; Zeichner \& Liston, 1991). Various authors have presented classifications of reflection which include a category identified as critical reflection, the focus of our work, but what is missing from much of the research and scholarship on critical reflection is a conceptual/theoretical framework linking means and ends. We draw from theories of adult development to make this connection in our work.

Many adult development theories provide an operational definition of human effectiveness that indicates the most adequate mode of processing information and interpreting environmental cues or stimuli (Selman, 1980; Widick, Knefelkamp, \& Parker, 1984). These theories describe a process whereby individuals become increasingly able to take "self as object" and are capable of self-criticism (Dubow, Husemann, \& Eron, 1987; Kegan, 1983; Locvinger, 1980). In addition, they indicate that as mature individuals develop in their capacity to reason at more complex levels they gain greater access to their own reasoning processes (Hoyer, Rybash, \& Rooden, 1989). They are able to identify weaknesses in their own thinking (Hoyer et al., 1989), are more flexible in the application of knowledge
(Kitchener, 1986; Kitchener \& King, 1990a, b), can identify their assumptions about knowledge (Mezirow, 1990), and change from a focus on self to a focus on universal ethical principles when making moral decisions (Widick et al., 1984). These theories provide a framework for understanding individuals capable of engaging in critical reflection; capabilities of individuals who are critically reflective parallel characteristics of individuals functioning at mature levels of development. ${ }^{2}$ We are not suggesting, however, that those individuals capable of critical reflection will necessarily engage in such reflection, nor are we arguing that critical reflection is "stage-like" but, rather, that many of the characteristics of individuals at higher levels of development are similar to the characteristics of critically reflective teachers. We suggest that mature development may be a necessary condition for critical reflection but not a sufficient condition.

Drawing from theories of adult development we have opcrationalized critical reflection as (1) recognizing limitations in sociocultural, epistemic, and psychological assumptions, (2) acknowledging and including multiple perspectives, (3) considering the moral and ethical consequences of choices, and (4) clarifying reasoning processes when making and evaluating decisions. The relationship among critical reflection, taken-for-granted assumptions, and development is apparent. The ability to "stand back" from one's worldview, to reflect critically, requires being able to take "self as object," to be self critical, to identify weaknesses in one's thinking, and to identify assumptions about knowledge. These habits of mind provide the scaffolding for critical reflection and for the recognition of the limitations in one's sociocultural, epistemic, and psychological assumptions. We now discuss the relationship between critical reflection and computer conferencing.

\section{Computer Conferencing and Critical Reflection}

Computer confercncing is an on-going communication medium which allows participants to exchange ideas and information with other users regardless of the time of day or the distance between users. Conferences are designed from software which resides in a host computer and are accessed by users either with a direct connection or via a terminal or a microcomputer 
and a modem. Although the benefits of conferencing have been investigated in other areas, conferencing has not been widely examined as a component of teacher education programs (Bull, Harris, Lloyd, \& Short, 1989; Carey, Carey, Willis, \& Willis, 1991; Harrington, 1991a, b; Merseth, 1991). When it has been examined, it has not been in relation to critical reflection and professional development; however, computer conferencing can be uniquely structured to foster both.

Computer conferencing activities can do so by providing opportunities for nondominated dialogue, developing norms of collegiality and joint problem solving, and including the perspectives of multiple educational constituencies. Nondominated dialogue lessens the power imbalance found in most classroom discussions and encourages the freedom of expression that is the foundation of a democratic education (Bullough \& Gitlin, 1991; Burbules \& Rice, 1991; Dewey, 1966; Strike, 1991). Norms of collegiality and joint problem solving encourage educators to see that both practice and theory can be informative in the resolution of educational problems. It can, as well, lead teachers to an "owning" of educational dilemmas and the generation of solutions specific to a context rather than relying on external authorities for solutions to classroom dilemmas (Cuban, 1992; Griffin, 1989; Harrington \& Garrison, 1992; Smyth, 1989). The inclusion of multiple educational constituencies provides an awareness of the complex context and taken-for-granted assumptions influencing and fostering the cultural and historical roots of what and how different individuals and communities know. This inclusion also provides insight into the political and ethical consequences of those different ways of knowing. In addition, conferencing provides a non-threatening avenue for holding one another accountable for choices and decisions as well as time to reflect on and discuss the ways problems are framed and how that framing is reflected in the solutions generated (Galegher, Kraut, \& Egido, 1990; Harrington, 1993; Rapaport, 1991; Schön, 1979; Sproull \& Kiesler, 1991). All of these goals are difficult to achieve in the regular classrooms and yet they provide the necessary scaffolding for the development of critical reflection (Habermas, 1984; Kurfiss, 1983; Mead, 1934; Pcrry, 1970; Rest, 1986; Selman, 1980; Sprinthall \& ThiesSprinthall, 1980).
The computer conferencing exercise that serves as the focus for this discussion, the Dialogical Community Exercise (DCE), is incorporated in the first course elementary certification students are required to take once they have been admitted into the School of Education. Using the concept of nondominated dialogue as a foundation for the structure of the exercise, only students participate on the conference and they do so anonymously. In this way, we avoid the power imbalance that can exist in classrooms and encourage a freer exchange of ideas and arguments. In structuring the conference around the concept of nondominated dialogue, we provide a non-threatening environment wherein students can share the diverse perspectives they hold on educational issues and remove inhibitors found in traditional conversational exchanges that may prohibit access to students' takenfor-granted assumptions. Students are encouraged, as well, to address the consequences of action and the reasoning behind the choices they and their peers make.

The DCE is designed around the courses' five components - schools and society, teaching, learning, curriculum, and ethics. The specific focus for cach part of the excrcise is provided by a particular policy issue that is of concern to teachers and is also related to the component of the course it is aligned with. When discussing teaching, for example, site-based management is the policy issue that serves to focus the discussion. Each dialogue begins with an "item" which described a dilemma a teacher might face in his or her professional life. ${ }^{3}$ The items in each dialogue are generated by the teaching assistant along with two or three students who are assigned the role of facilitators - each dialogue had a minimum of two student facilitators for each week. In addition to writing the item, facilitators were required to facilitate the discussion which involved participating more often and trying to move the discussion forward.

The overarching aim of the exercise is to facilitate the development of students' communicative competence. Communicative competence leads to meaning perspectives that are more open, integrated, and inclusive and, according to Bowers (1987),

requires, beyond individual facility in speech situations, a knowledge of relevant isśues and the con- 
ceptual frameworks that influence our way of thinking. The unique comlributions that public education can make to the student's communicative competence include: (1) providing an understanding of the cultural forces that foster change: (2) providing knowledge of cultural traditions that will enable students to exercise a judgment about those elements of the culture that are worth preserving: and (3) providing a method of thinking that enables students to see decisions in terms of relationships, continuities, disjunctions, and tradeoffs. In short, communicative competence can be understood as the outcome of being culturally literate, which ... (is) the ability to read or decode the taken-for-granted assumptions and conceptual categories that underlie the individual's world of experi. ence. (p. 2)

Taken-for-granted assumptions, if unrecognized, place limitations on our ability to actively, persistently, and carefully consider beliefs or supposed forms of knowledge; the grounds that support them; and the consequences to which they lead - our ability to reflect (Dewey, 1933). Knowing full well that it is impossible to recognize all taken-for-granted assumptions, particularly those that are "regarded as too true to warrant discussion" (Douglas as cited by Bowers, 1988, p. 98) we, nevertheless, believe that prospective teachers should be provided with opportunities to notice at least some of what they fail to notice. We believe computer conferencing activities can be structured to do so and as a consequence students should be better prepared to deal with the "contradictions generated by rapid, dramatic changes and diversity of beliefs, values, and social practices (that) are the hallmark of modern society" (Mezirow, 1991, p. 3) and, in turn, better able to address teaching's full complexity. The methods we used to gain insight into the relationship among our students' taken-for-granted assumptions, their development as professionals, and computer conferencing activities will now be discussed.

\section{Methods}

As thought takes form in computer conferencing it becomes text and, once fixed, we can critically examine students' thinking and reflect on their understanding and misunderstanding of the phenomena of teaching. In this study we did so by examining students' taken-for-granted assumptions as evinced in the conferencing text. A critical interpretive analysis of the text was completed (Berger, 1991; Lincoln \& Guba, 1985) by analyzing all responses to one of the five conference discussions and the entire conference participation of two students selected to represent complex and less complex levels of professional development. This assessment was based on their work in a practicum that placed them in a public school classroom for 9 hours a week, in-class discussions and written work, pre-testing, and conference participation. The data was examined with a focus on the language students used; the epistemic, psychological, and sociocultural assumptions that supported positions presented; and the power relationships, social roles, and ethical consequences reflected in the discussions. Four levels of coding were completed. First, we examined the text to determine what students were saying both in general and in regard to the topic being discussed. During the process of this analysis we, second, began to identify patterns of assumptions that became apparent throughout the discussions. The text was re-analyzed to identify specific assumptions supporting the students' discussions. Third, we coded those assumptions by category, that is, sociocultural, epistemic, psychological. Finally, the selected text was read once more to identify changes in frequency of any of the three types of assumptions as well as change in how students responded to or challenged each others' assumptions with a focus on relationships, roles, and consequences of choices and actions. The authors read and coded the data independently with discrepancies negotiated until agreement was reached.

\section{Analytic Framework}

"Because human functioning is so infinitely complex, rich, and multidetermined, it is rarely easily reducible or codable on the basis of one scheme or perspective, no matter how thoroughly studied and conceived the scheme might be" (Selman, 1980, p. 12). We, therefore, drew from the literature and research on teacher education, reflective practice, and adult development to develop our analytic frame. Using diverse bodies of research and scholarship helped us develop a "whole picture" of teacher development. Drawing from multiple developmental models ---moral (e.g., Gilligan, 1982; Kohlberg, 1984; Rest, 1986), ego (e.g., Kegan, 1983; Loevinger, 1980), and 
epistemological (e.g., Belenky, Clinchy, Goldberger, \& Tarule, 1986; Kitchener \& King, 1990a, b; Perry, 1970) - allowed us to investigate the inter-relatedness and interconnectedness of these different development schemes to the preparation of critically reflective practitioners. The literature and research on teacher education and reflective practice helped us better understand the relationship between aspects of critical reflection and mature development (see note 2).

\section{Data Source}

The transcript of The Dialogical Community Exercise (DCE) was our primary data source. Additional documentation was provided through observations, additional written assignments, and course evaluations. For this study, we analyzed 117 pages of dialogue and 217 responses. The text was generated in an introductory teacher education course that is part of a block of courses students take once they are accepted into the School of Education. In addition to this course, the block includes an educational psychology course, a reading methods course, and a 9 hour practicum in an elementary school classroom. Because the instructor did not participate on the conference, the text was completely generated by the 26 students enrolled in the course. Nine were non-traditional students - they had received degrees or had returned to school after an extended absence. The remaining 17 were traditional students - college juniors or seniors, 19-20 years old. Of the total, three students were male and three were students of color. The makeup of the class was comparable to other cohorts of elementary education students at the University. Although the student population may not be representative of the majority of teacher education students - they are enrolled in a highly competitive, very expensive public institution and their college entrance exam scores and socio-economic status are considerably above average - the results are informative nonetheless. We now discuss our findings.

\section{Findings}

\section{Taken-for-Granted Assumptions}

To answer our first question - do conferencing activities generate opportunities for the identification and discussion of taken-forgranted assumptions and, if so, what types of assumptions - we examined students' responses to a discussion that addressed the responsibilitics that parents and schools have for a child's education. This was the first discussion in the conference and was included with the section of the course dealing with schools and society. The policy issue serving as a focus was school choice. As would be expected, students brought numerous taken-for-granted assumptions to the discussion.

Sociocultural assumptions. Most noticeable were students' sociocultural assumptions, in particular, the similarity in those assumptions. Although students' assumptions about how much influence parents should have on their child's education varied, the majority of students assumed that all parents had the time and commitment to be an active partner in their children's education, the right to remove their children from schools they did not support, and the resources to place them in alternative schools.

Parents should always be a part of their children"s education. Parents should know what their children are doing in the classroom. It is important for parents to ask what their children are doing in the classroom. It is important for parents to ask their children when they get home from school that day how their day was. Parents should be aware of what is happening to their children when they are at school.

Parents should be providing education in the home. It only takes a half hour a night to read to a child or to help them with homework. It is the responsibility of the parent to do their part in the education of their children.

Parents have some control over their child's education. They can pick the community they wish to live in and thereby have some choice in what school their child attends. If a parent is displeased with the education dispensed by a school then the child could be removed and enrolled in a private school. As stated before, parents can always supplement a child's education by using tutors or teaching the child additional information at home.

If parents don't like the fact that their child is attending a so-called "liberal" school, then they should search for a new school, perhaps a private school where the rules are a little more strict and traditional.

Parents have a choice about whether to educate their children at home themselves and with their own values, or to send them to a public or a private school to be taught by a trained professional. 
Additional assumptions supported these. Many students expressed the belief that parents could provide input into their children's education through active participation in the PTA and by observing their children's classes and sharing their concerns with the teacher and administrator.

Although a few students questioned assumptions made by others.

\begin{abstract}
Given that school is "mandatory" just how much of a choice is involved?... If you don't have the money to place your child in a private school which meets your philosophical and educational requirements (assuming such exists where you can get to it), yet you are mandated to send your kids to "approved" schooling [sic]. Just how much "parental choice" of any sort is involved?

It is not always the case that parents take enough initiative in educating their children. While for some home life can be a very secure and stimulating place, for others it may be very vacant with parents who do not feel they have the time.

If [parents] are economically disadvantaged they may not have any choice in terms of other schools for their child to attend. Perliaps schools of choice, voucher systems for private tuition and less restrictions on home schooling could act as a safety net to avoiding imposing our will on individuals who do not fit the established mold.
\end{abstract}

the overwhelming majority of students failed to consider these positions.

Students' sociocultural assumptions about schooling seemed to reflect a commonalty of their experiences in and with schools - upper middle class experiences -- and limited the perspectives they were able to take. Although 9 of the 26 students participating were non-traditional students, alternative perspectives were seldom expressed. The consensus seemed to be that it is the responsibility of parents to be active participants, with school personnel, in their children's education. Conference participants offered no suggestions for gaining the input of parents not empowered to do so. In fact, most did not even acknowledge this as an issue. If students fail to move beyond their own "frame of reference" it is unlikely they will adequately meet the needs of a changing school population. Helping students identify their frames of reference and how they may limit what they think and do as teachers must be a priority of teacher education programs.
Epistemic assumptions. How our students know has significant implications for the kinds of teachers they will become. To see a teacher as an authority with knowledge to transmit implies much different responsibilities than seeing a teacher as part of the learning process in partnership with others. Students' epistemic assumptions provide insight into their thinking about their role in the teaching and learning process and these assumptions were embedded in the discussion. They ranged from the belief that teachers have the "best" answers regarding educational issues, to the belief that because there are so many perspectives on an issue educators should decide - a default approach - to a belief that the best answers are obtained by soliciting multiple perspectives on given issues and reasoning together.

\begin{abstract}
While there are some parents who really do know what is best for their child in terms of education, there are many others who think they know what's best, but in reality, are not capable of making these kinds of choices. Teachers and members of the school administration are trained professionals, just as doctors or lawyers. Should parents have the right to treat their child's illnesses?

Every parent represents a different opinion. How can all of these strongly held opinions and wishes be honored? Since the answer to that questions has to be that they can't, it would seem logical to leave these decisions up to a highly educated group of "professionals".

I would hope that parents would try to keep an open mind and understand the reasoning of the teachers, the people behind the curriculum and so on. But I also feel, on the other hand, that teachers and schools should listen to parents' concerns. If you could keep in mind that they both have the same interest. what is best for the child, perhaps they could work together instead of argue about who is right or wrong. I strongly agree with a previous participant that they really need to work together. By integrating several viewpoints, a better outcome may result.
\end{abstract}

There should be an equal partnership between parents, teachers, and administrators, with input from students and the community also. The process is dynamic: Society is always changing along with calls for the schools to respond in one way or another.

Additional epistemic assumptions reflected students' beliefs about their responsibilities in fostering the "knowing" of their students.

Parents need to remember that the purpose of schools is to produce open-minded independent thinkers who will become beneficial members of American society. In order to do this, teachers must present factual 
information to the students showing both sides to every issue.

It's not a matter of reading and absorbing material and believing it to be the truth - it's a matter of discussing the author's viewpoint and why the author thinks in this manner, how things are different today and why. But this viewpoint does depend on one very important thing; that we, as teachers, do our job in a professional, unbiased manner ... by providing the information possible for the child to decide what is right and/or wrong for themselves.

It is the presentation of the material in an unbiased, questioning, analytical way that lets the child explore what true knowledge is: The seeing of all material before him or her and being able to choose what to believe and what not to believe.

And what better place than the classroom, to raise questions, and present both sides of the issue? I'm not saying that all grade levels will deal with all of this or that all school districts will either, but I simply won't stand by and watch children become vegetables in the classroom: memorizing and regurgitating what they memorized; I want them to be able to think for themselves, using the influences of their homelife and the material presented in the schools.

The apparent openness in these epistemic assumptions must be regarded with a great deal of caution for, although students seemed to value the presentation of multiple perspectives and the development of "open-mindedness" in students, they very seldom addressed how they would help students to make decisions among competing positions other than letting them decide for themselves - a stand which appears very relativistic. Although Perry's (1970) work (referring to this position as multiplistic) and the work of adult developmental psychologists suggests that this is not unexpected in college juniors, this stance is certainly not one we want our students to leave our programs with. The conferencing experience, in relation to the item analyzed, did not seem to move students forward in this regard.

The students also failed to question whether some of the fundamental epistemic assumptions they brought to the discussion would be supported by others. For example, at no time did thcy consider if all people would support, as an aim of education, the development of openmindedness in students. They were firmly embedded in their own shared assumptions, seeming to see them as "too true to warrant discussion". It should be noted that the contributions of a small number of students reflected more complex levels of development in that they questioned not only others' assumptions but their own assumptions as well. In addition, they presented well-reasoned arguments for their choices that reflected an acknowledgment of teachings' ambiguity. The participation and influence of one of these students is discussed later in this paper.

Psychological assumptions. Students' cpistemic assumptions reflect psychological assumptions addressing how they perceive their prospective role as teachers. ${ }^{4}$ Research on ego development and moral development provides additional insight into students' psychological taken-forgranted assumptions. Research on ego development suggests that for some individuals their role as teacher revolves around maintaining a relationship with the children in their care. For others the primary responsibility is to themselves as teachers and to the organization that supports that role. Still for others their perceived professional responsibilities reflect an acknowledgment of the multiple participants in the educational process as well as an ultimate reliance on their own self-definition (Cummings \& Murray, 1989; Kegan \& Lahey, 1984; Spatig, Ginsburg, \& Liberman, 1982). Students' comments reflected this variability in who they perceive has the ultimate authority and in how they should conduct themselves as professionals.

It is the state's responsibility to see that the teachers placed in the schools are competent and morally suitable for the profession.

I think that self-esteem of the students should always be considered first and foremost in making decisions.

Although I believe that we, as teachers, are ultimately responsible to the students, I don't think that I could continue working in an environment where my opinion and choices are not respected. I would try to talk with my colleagues to see if any of them are in agreement with me, because as a group, we could make a difference. Yet if not one saw my point of view, I would probably find another place to teach because how can a teacher do a good job if he or she is unhappy with his or her co-workers and administration?

In response to the question about who does a teacher ultimately feel responsible to, parent or district [sic]. My answer is that I want to be responsible to the parent. I mean it is their child but what if I feel they are wrong? Then there is the district. If I disagree with them they ultimately decide if I work or not. So my answer is myself. I have to be responsible to myself. I guess I am the one who has to go home at night 
and feel like I did not only a good job but the best job possible. If more than 2 days pass by and I feel like I did not live up to my personal responsibility that is the day I should stop teaching.

In addition, psychological assumptions addressing the moral dimension of the educative process were apparent throughout the discussion. Research on moral development and teaching suggests a relationship between how teachers perceive the needs of individual students, authority and management and their moral development (Johnston, 1989; Johnston \& Lubomudrov, 1987). Teachers who are primarily responsive to rules and regulations are developmentally different from teachers who first focus on the individual needs of the students in their care. How the rights of the individual are perceived in relation to the good of the community is also indicative of an individual's moral perspective and underlying taken-for-granted assumptions. Noteworthy in the conference discussion analyzed is the assumption of many students that teachers can and should strive for moral neutrality.

No amount of education can prepare someone to decide what morals and values should be conveyed to America's children.

Some parents may hate having fifth graders learn about AIDS. Yet, if the teacher explains it without using her values and is unbiased it could be helpful.

I think that teachers have no right to give moral lessons or political lessons. Those things should be left up to the parents to do at home. I think I'm going to have a difficult time as a teacher because, though I want students to respect each other and be friends. I do not always believe that it is my place to step in and give them a lesson in morality.

We, as teachers, (should) do our job in a professional, unbiased manner. We shouldn't be preaching morals and values, but providing the information possible for the child to decide what is right or wrong themselves.

At no time did students recognize that moral neutrality, as impossible as that is to achieve, is a moral stance - one that resembles ethical relativism. As with other assumptions, although their beliefs about the moral responsibilities of teachers were sometimes questioned -. "What are values? What are so called "family values"? Does that really mean something?" and "(Teachers) may be attempting to cater to the "good of society' but what society is that?" the questions were not answered. Students did not clarify psychological assumptions dealing with the moral dimensions of teaching, and only rarely did they recognize resulting limitations.

This analysis confirms that computer conferencing activities can be a rich source of sociocultural, epistemic, and psychological assumptions. Students' responses generated all types of assumptions. Although assumptions were made explicit there was little discussion leading to the clarification of individual participants' assumptions, even when other participants questioned them. This initial analysis suggests that an extended discussion may be necessary before questions about taken-forgranted assumptions are addressed. Our second level of analysis provides further insight into this issue. Analysis of the full conference text by participants has implications for the role that specific students may play in modeling and fostering the development of critical reflection and in prompting others "to think through the consequences of their opinions for others." This analysis also provides insight into the relationship between student development and how students responded to or challenged each others' assumptions.

\section{Relationship Between Development and Taken- for-Granted Assumptions}

There is a very clear difference in the conference participation of the students selected to represent complex and less complex levels of professional development. One of the most apparent differences was the self-contained nature of the developmentally less complex student's discourse. She directly responded to each question that initiated an item rather than conversing with other participants. In addition, the takenfor-granted assumptions that were most apparent were specifically related to each question as well. Her thinking seemed bounded by, and limited to, the specific questions asked. For example, when dealing with the issue of school choice her sociocultural embeddedness permeated her responses. When addressing sitebased management, assumptions reflecting her perceptions of her role as a teacher were most apparent.

Initially, she was very sure of how things should be and did not question or recognize that the schooling process may be much more com- 
plex than she perceived it to be. This certainty also showed up in her initial perception of her needs as a professional. For example, she stated early in the discussion, "As a teacher, I would like some sort of set curriculum. If not, how am I supposed to know what to teach my students?"

As the conference progressed she appeared to become less certain. She began to consider more than one perspective in her response and exhibited more contradictions in her thinking while not seeming to be aware of those contradictions. Her participation could be interpreted as a beginning move from dualistic to multiplistic thinking (see Perry, 1970). By the end of the conference, as the following quote suggests, she was becoming more aware of the complexity of the teaching and learning process:

\begin{abstract}
Students' beliefs, values, and attitudes affect ... (their conceptual understanding). Teachers need to be aware that because of students' cultures they will all have different understandings of subjects. Teachers have to take advantage of what cach student has to offer the class.
\end{abstract}

She also began to raise questions she did not seem able to recognize at the beginning of the conference such as, "would I be able to teach my students without teaching them my beliefs?"

This students' conference participation suggests she is making a move from certainty to less certainty, a move from dualism to relativism. Although she continued to rely on the authority of texts, other professors, and her cooperating teacher to make decisions, she was beginning to see that teaching is a highly complex activity requiring teaches to, as she said, "make decisions in environments which are both unpredictable and interactive."

In contrast, the student who seemed to be operating at a much more mature level of development began her participation addressing the complexity and ambiguity of the schooling process.

There should be an equal partnership between parents, teachers, and administration with input from students and the community also. The process is dynamic: society is always changing along with calls for the schools to respond in one way or another. We reallfi need to have checks and balances on the whole system and allow parents options. ... The whole situation is similar to the problem of a national curriculum and the diversity that exists in our nation. On one hand we want to allow the community to have a say in and a power to change their schools.
This allows them to address local issues and build on local strengths. But, if a community makes choices that will limit the ability of matriculating students to function in other parts of the nation there needs to be some way to check its course.

This student addressed teaching's complexity throughout her conference participation. In addition, she modeled critical reflection for the other participants. She frequently presented multiple viewpoints in her discussions, she would make a choice from among those competing positions and present a justification for her choice, often focusing on the ethical consequences of her choice. She seemed to consider the full variety of assumptions in her reflection. She was not item bound as the first student was and raised important questions about sociocultural, epistemic, and psychological assumptions throughout her discussions.

I wonder what kinds of mistakes I will make in the name of "truth" in the classroom, that are really reflections of my own cultural values... Too many of our expectations seem culturally bound to the dominant class!

Knowledge and understanding are moving targets, we don't as teachers, know absolutes. It is good for our students to argue their point of view as long as they are required to support it and listen to others.

I would like to have a principal who takes input from the teachers and is in touch with the students, but realistically speaking, I am going to really guard my time for my children in the classroom (and my kids at home). Unless decisions are going to impact them directly, I am happy to leave administration to the administrators.

Although there was little change in this student's participation throughout the conference she, and other students like her, serve an important role in generating the disequilibrium that may prompt growth in less mature individuals (Berkowitz, Oser, \& Althof, 1987; Sprinthall \& Thies-Sprinthall, 1980).

This initial analysis suggests that conferencing activities can provide insight into the relationship between students' awareness of their own and others' taken-for-granted assumptions and their development. Equally important, we found differences in the nature of the participation of students functioning at different levels of development. The developmentally mature student directly addressed the other participants in the conference, asking them specific questions, holding them accountable for their positions. She 
actively participated in a conversation - the majority of her responses were directly related to responses of other students. In contrast, the less mature student most often responded to the specific questions being asked. She conducted a soliloquy rather than a dialog. Although, in general, she fulfilled her perceived obligations as a student rather than actively participating as a learner, toward the end of the conference she began to take part in the "conversation" - she began to reflect.

\section{Conclusions and Implications for Further Study}

The study discussed here was guided by the following two questions. First, do conferencing activities generate opportunities for the identification and discussion of taken-for-granted assumptions and, if so, what types of assumptions? Second, do conferencing activities provide insight into the relationship between student development and the ability to identify and clarify taken-for-granted assumptions?

Our findings suggest that although conferencing activities can be structured to generate a rich source of assumptions, students may not recognize them as such. Even when other students draw attention to them, students often do not respond. If we hope to help our students develop the habits of mind and dispositions to become critically reflective educators this is an issue that needs further study and conferencing activities may be a vehicle for doing both. We also found that a student's level of development appears to be related to her or his ability to identify and clarify taken-for-granted assumptions. Further study may provide insight into the specific role that different students play in fostering the professional development of their peers. Questions that might be raised include: Does any "mis-match" lead to the questioning of assumptions? Do students functioning at higher levels of development generate more reflection on assumptions than those functioning at lower levels of development? Will instruction in "reasoning" lead students to a more in-depth questioning of assumptions? Will this work more effectively with some students? Which ones?

Because there is some indication from this analysis that as the conference progressed more questions regarding assumptions were being raised by the participants, further study appears to be warranted concerning the relationships between the progression of the conference, the topics of discussion, and the identification and clarification of taken-for-granted assumptions. For example, do some topics generate certain types of assumptions more than others or, do some topics lead students to confront their taken-for-granted assumptions more than others? In addition, what role does the development of a "learning community" play in students holding each other accountable for their opinions? That is, as the class progresses and students become more comfortable do they raise more questions or fewer? Conferencing activities do appear to be uniquely suited for generating discussions of taken-for-granted assumptions. Although we have yet to determine the best way to help students confront them in an educative way, computer conferencing activities do seem to hold significant potential for helping us prepare our students as critically reflective professionals. In particular, conferencing activities seem especially suited to helping students notice how what they fail to notice shapes their thoughts and deeds.

\section{Notes}

${ }^{1}$ See Soltis (1981) on sociocentric knowing. As he indicates, there may not be agreement of what different scholars mean when they use the term but for our purposes sociocentric knowing means accepting that "knowledge claims, epistemological inquiry, and theories of education and human development need to take into account the complex reciprocal relations between an individual and his or her biological, social, and cultural inheritance, between individuals and groups, between public knowledge systems and the structure of both the natural and social worlds, and between any relevant mix of these in multiple combination" (p. 98).

${ }^{2}$ See Bullough \& Gitlin, 1991; Grimmet \& Erickson, 1988; Grant \& Zeichner, 1984; Gore, 1987; and Smyth, 1989 for discussions of reflection and critical reflection.

${ }^{3}$ The DCE is made possible with Confer II ${ }^{\mathrm{TM}}$, a computer conferencing system that operates on the University's IBM 3090 mainframe computer. See Rapaport (1991) for a further discussion of Confer.

${ }^{4}$ We use the literature on ego, moral, and epistemological development in adults as a sensitizing device for our understanding of psychological assumptions. Because we are all makers of meaning, who are knowing and valuing individuals there is a great deal of overlap in taken-for-granted assumptions. As Palmer (1987) and others suggest, our way of knowing influences our "ethic." In similar ways, our philosophies of reality - our ego development --. reflects our epistemologies and our moralities. 


\section{References}

Belenky, M., Clinchy, B., Goldberger, N., \& Tarule, J. (1986). Women's ways of knowing. New York: Basic Books.

Berger, A. A. (1991). Media research techniques. Newbury, CA: Sage.

Berkowitz, M., Oser, F., \& Althof, W. (1987). The development of discourse. In W. M. Kurtines \& J. L. Gewirtz (Eds.), Moral development through social interaction (pp. 323-352). New York: J. Wiley and Sons.

Bowers, C. A. (1987). The promise of theory: Education and the politics of cultural change. New York: Teachers College Press.

Bowers, C. A. (1988). The cultural dimensions of educational computing: Understanding the non-neutrality of technology. New York: Teachers College Press.

Bull, G., Harris, J., Lloyd, J., \& Short, J. (1989). The electronic academically village. Journal of Teacher Education, 40(4), 27-31.

Bullough, R., \& Gitlin, A. (1991). Educative communities and the development of the reflective practitioner. In $R$. Tabachnick \& K. Zeichner (Eds.), Issues and practices in inquiry-oriented teacher education (pp. 35-55). London: Falmer Press.

Burbules, N., \& Rice, S. (1991). Dialog across difference: Continuing the conversation. Harvard Educational Review, 61, 393-416.

Calderhead, J. (1989). Reflective teaching and teacher education. Teaching and Teacher Education, 5, 43-51.

Calderhead, J. (1991). A review of encouraging reflective practice in education: An analysis of issues and programs. Journal of Teacher Education, 42(2), 153-155.

Carey; D., Carey, R., Willis, J, \& Willis, D. (Eds.). (1991). Technology and teacher education annual: 1991. Greenville, NC: Society for Technology and Teacher Education.

Cuban, L. (1992). Managing dilemmas while building professional communities. Educational Researcher, 21(1), 4-11.

Cummings, A. L., \& Murray, H. G. (1989). Ego development and its relation to teacher education. Teaching and Teacher Education, 5, 21-32.

Dewey, J. (1933). How we think: A restatement of the relation of reflective thinking to the educative process. Boston: $\mathrm{D}$. C. Heath and Co.

Dewey, J. (1966). Democracy and education: An introduction to the philosophy of education. New York: Free Press. (originally published in 1916)

Dubow, E. F., Huesmann, L. R., \& Eron, L. D. (1987). Childhood correlates of adult ego development. Child Development, 58, 859-869.

Galegher, J., Kraut, R., \& Fgido, C. (1990). Intellectual teamwork: Social and technological foundations of cooperative work. Hillsdale, NJ: Lawrence Erlbaum.

Gilligan, C. (1982). In a different voice. Cambridge: Harvard University Press.

Gore, J. (1987). Reflecting on reflective teaching. Journal of Teacher Education, 38(2), 33-39.

Grant, C., \& Zeichner, K. (1984). On becoming a reflective teacher. In C. A. Grant (Ed.), Preparing for reflective teaching (pp. 1-19). Newton, MA: Allyn and Bacon.

Griffin, G. (1989). Coda: The knowledge driven school. In M. C. Reynolds (Ed.), Knowledge base for the beginning teacher (pp. 277-286). Oxford: Pergamon Press.
Grimmet, P. P., \& Erickson, G. L. (1988). Reflection in teacher education. New York: Teachers College Press.

Harrington, H. L.(1991a). Normal style technology in teacher education: Technology and teacher education. Computers in the Schools, 8, 49-59.

Harrington, H. L. (1991b). Using technology in teacher education: Facilitating development or maintaining the status quo? Technology and Teacher Education Annual: 1991 (pp. 338-343). Greenville, NC: Society for Technology and Teacher Education.

Harrington, H. L. (1993). The essence of technology. Journal of Teacher Education, 44(1), 5-15.

Harrington, H. L., \& Garrison, J. (1992). Cases as shared inquiry: $\Lambda$ dialogical model of teachcr preparation. American Educational Research Journal, 29, 715-735.

Hoyer, W. J., Rybash, J. M., \& Roodin, P. A. (1989). Cognitive changes as function of knowledge access. In M. L. Commons, J. D. Sinnott, F. A. Richards, \& C. Armon (Eds.), Adult development: Vol. 1. Comparisons and applications of developmental models (pp. 293-305). New York: Praeger.

Johnston, M. (1989). The moral reasoning of teachers' understanding of individualized instruction. Journal of Moral Education, 18, 45-59.

Johnston, M., \& Lubomudrov, C. (1987). Teachers level of moral reasoning and their understanding of classroom rules and roles. The Elementary School Journal, 88, 65-77.

Kegan, R. (1982). The evolving self: Problem and process in human development. Cambridge, MA: Harvard University Press.

Kegan, R., \& Lahey, L. L. (1984). Adult leadership and adult development: A constructivist view. In B. Kellerman (Ed.), Leadership: Multidisciplinary perspectives (pp. 199-230). Englewood Cliffs, NJ: Prentice-Hall.

Kitchener, K. S. (1986). The reflective judgment model: Characteristics, evidence, and measurement. In R. A. Mines \& K. S. Kitchener (Eds.), Adult cognitive development. Methods and models (pp. 76-91). New York: Praeger.

Kitchener, K., \& King, P. (1990a). The reflective judgment model: Ten years of research. In M. Commons, C. Armon, L. Kohlberg, F. Richards, T. Grotzer, \& J. Sinnott (Eds.), Adult development: Models and methods in the study of adolescent and adult thought (pp. 63-78). New York: Praeger.

Kitchener, K. S., \& King, P. M. (1990b). The reflcctivc judgment model: Transforming assumptions about knowing. In J. Mezirow (Ed.), Fostering critical reflection in adulthood. A guide to transformative and emancipatory learning. San Francisco, CA: Jossey-Bass.

Kohlberg, L. (1984). Essays on moral development. Vol. II. The psychology of moral development. New York: Harper Row.

Kurfiss, J. (1983). Intellectual, psychosocial, and moral development in college: Four major theories. Revised. ERIC reproduction number ED 295534.

Lincoln, E., \& Guba, E. (1985). Naturalistic inquiry. Newbury, CA: Sage.

Loevinger, J. (1980). Ego development: Conceptions and theories. San Francisco, CA: Jossey-Bass.

Mead, G. H. (1934). Mind, self, and society. Chicago, IL : University of Chicago Press.

Merseth, K. (1991). Supporting beginning teachers with computer networks. Journal of Teacher Education, 42(2), 
$140-147$.

Mezirow, J. (1990). Fostering critical reflection in aduithood. San Francisco: Jossey-Bass.

Mezirow, J. (1991). The transformative dimensions of adult learning. San Francisco: Jossey-Bass.

Palmer, P.(1987, November). Community, conflict, and ways of knowing. Change, 19, 20-25.

Perry, W. G. (1970). Forms of intellectual and ethical development in the college years. New York: Holt, Rinehart and Winston.

Rapaport, M. (1991). Computer mediated instruction: Bulletin boards, computer conferencing, electronic mail, and information retrieval. New York: John Wiley \& Sons.

Rest, J. (1986). Moral development: Advances in research and theory. New York: Praeger.

Richardson, V. (1990). The evolution of reflective teaching in teacher education. In R. T. Clift, W. R. Houston, \& M. Pugach (Eds.), Encouraging reflective practice in education (pp. 3-19). New York: Teacher College Press.

Schön. D. (1979). Generative metaphors: A perspective on problem-setting in social policy. In A. Ortony (Ed.), Metaphor and thought (pp. 254-283). London: Cambridge University Press.

Selman, R. (1980). The growth of interpersonal understanding: Developmental and clinical analysis. New York: Academic Press.

Smyth, J. (1989). Developing and sustaining critical reflection in teacher education. Journal of Teacher Education, 26(1), $2-9$.
Soltis, J. (1981). Education and the concept of knowledge. In J. Soltis (Ed.), Philosophy and education: Eightieth yearbook of the National Society for the Study of Education (pp. 95-113). Chicago, 1L: University of Chicago Press.

Spatig, L., Ginsburg, M. B., \& Liberman, D. (1982). Ego development as an explanation of passive and active models of teacher socialization. College Student Journal, 16,315325 .

Sprinthall, N., \& Thies-Sprinthall, L. (1980). Educating for teacher growth: A cognitive developmental perspective. Theory into Practice, 19, 278-286.

Sproull, L., \& Kiesler, S. (1991). Connections: New ways of working in the networked organization. Cambridge, MA: MIT Press.

Strike, K. (1991). The moral role of schooling in a liberal democratic society. In G. Grant (Ed.), Review of research in education (pp. 413-483). Washington. DC: American Educational Research Association.

Widick, C., Knefelkamp, L., \& Parker, C. A. (1984). Student development. In U. Delworth \& G. R. Hanson (Eds.), Student services. A handbook for the profession (pp. 75-116). San Francisco, CA: Jossey-Bass.

Zeichner, K., \& Liston, D.(1987). Teaching students to reflect. Harvard Educational Revien, 57, 23-48.

Submitted 18 August 1993 Accepted 14 December 1993 